results of campaigns against sleeping sickness in the French Cameroons (by Médecin Colonel Vaucel, vol. i, parts I and 2, 1942), while evidence for congenital malaria and its important effects on infant mortality is discussed with reference to data from the Cameroons, by Dr. Perves, vol. ii, part 2, I943.

\title{
Inter-territorial Language (Swahili) Committee
}

THE report of activities during the year 1942 indicates that though war-time conditions have imposed certain restrictions, yet in some respects the Committee has found increased opportunities and wider scope for its work. In the words of the report, "Throughout the year contact has been maintained with the Information Departments of both Tanganyika Territory and Kenya Colony as well as the newly established "Army Education Corps", regarding publications in Swahili and courses of instruction in that language, particularly in Nairobi. . . . A quickening interest in Standard Swahili and the more recent literature in Swahili is evidenced by increasing inquiries from all parts of the East African Dependencies. With the movement of troops and the increased facilities for travel the demand for a common standard of orthography has been repeatedly expressed. An example of this is the request for the Committee to produce a standard version of "The Lord's Prayer" and " The Apostles' Creed " that could be adopted by all shades of missionary effort.'

Contacts have also been established with certain centres in the Belgian Congo, with a view to the co-ordination of 'Kingwana' with Standardized Swahili. Eight new works in Swahili have been published, the majority being printed locally by the presses of local missions or by the C.M.S. Bookshop, Nairobi. The manuscripts of twenty-five additional works were submitted to the Committee's readers, of which four were tribal histories, one a work of fiction of outstanding merit by an African author, and one a translation of The Battle of Brittin. Other translations have been made by the Committee staff, and are awaiting publication till paper restrictions permit; assistance has also been given in Swahili broadcasts for schools.

One hundred and twenty-two entries were received for the ' Swahili Essay Competition '; fifteen manuscripts were submitted for the 'Swahili Authorship Competition', four of which showed distinct literary ability. The 'Swahili Essay Competition for pupils in Schools for Europeans', held in that year for the first time, produced four essays, all of a satisfactorily high standard in composition and expression, and showing a remarkably good grip of the language.

\section{Fisk University: Program of African Studies}

From America comes a Program of African Studies which has been added to the regular curriculum of sociology and anthropology in Fisk University. The Program is described in a short booklet by Dr. Mark Hanna Watkins and Dr. E. W. Smith. The latter is described as 'special consultant for the first year of the project'. As he is one of the founders of the International African Institute, members of the Institute will be pardoned if they feel an almost personal interest in, and goodwill towards, this new project of Fisk University, which would, in any case, have their warm good wishes. The School of Oriental and African Studies, of which the writer of this note is a member, will also welcome this extension of the study of African questions.

Dr. Watkins describes first the objectives of this new project. He sees the study of African languages and cultures as part of a liberal education for students who must more and more train themselves as citizens of the world. To be an Africanist, in fact, is part of being a humanist. But it has also its more practical implications. 'There is some basis for 
belief that in the Western Sudan especially, perhaps also in Nyasaland, and in other places, possibly, the native peoples themselves will have a larger share in the development of their country and in the shaping of their own destinies. It is not a disparagement of their inherent abilities nor of their present accomplishments to say that the Africans will need assistance in these tasks. The American Negroes, related as they are genealogically and historically to the Africans, would appear to be distinctively adapted for work in this sphere. Their claims for the privilege and opportunity of the undertaking must be supported by adequate preparation. The human urge for such alliance must be buttressed with the acquaintance, forbearance, and objectivity which result from long and careful study. Action that is based upon concrete data and rational attitudes will have greater efficacy than that which is motivated by romantic impulses alone, however noble may be the intentions that are bound up with the latter.

'A genuine acquaintance with the African, his world, and his problems, then, as a basis for aiding him in the management of his practical affairs, and the development of new vocational opportunities and careers for the sons and daughters of the University, must be recognized as one of the principal objectives of this program.'

The curriculum will include teaching and research in African languages, and it is hoped to obtain African informants who will also be encouraged to take courses of study. A Vai speaker is already taking part in the work. Ethnography, social anthropology, and special courses dealing with missions in Africa and with the problems of culture contact make up a large part of the curriculum.

The second part of this booklet from Fisk is by Dr. E. W. Smith and is called 'The Significance of a Program of African Studies'. He too sees the part that American Negroes may play, if they are trained for it, in helping Africans to adjust themselves to the impact of Western civilization on Africa and to take control, more and more, of their own affairs. And he points out what a deeper understanding of Africa might mean to American Negroes themselves in restoring to them the cultuval heritage that slavery stole from them. 'That revaluation, that self-revaluation of the Negro, which must precede or accompany any considerable further betterment of race relationships, will be fostered by these studies.'

Then, returning to the first theme, he writes, 'Every friend of the African would wish to help him in making adjustments amid the bewilderment into which he is thrown; but if we are to lend our effective aid there must be first a sympathetic inquiry into all his difficulties and the way out. Anthropological research of the older kind, that is, into the social life of the people as it used to be, has been helped forward by native Africans themselves. We need remind ourselves only of such men as Soga, Danquah, Dim Delobsom, and we may hope for still more contributions from them. American Negroes might well take their share in this research. Their experience of difficult social and economic adjustments in this country should be of aid in assisting inquiries in Africa. The International African Institute trained and sent out a number of men and women to investigate various problems; they produced valuable reports which have been published; and subsequently they have been much in demand as lecturess and professors at Universities. The Institute will no doubt resume these operations after the war; and there is no reason why some of its research fellowships should not be given to fully competent American Negroes. We hope also that other sources may be found. But it must be emphasized that effective work on these lines can be done only by very able and fully trained men and women. The possession of a dark skin is no infallible passport to the confidence which is essential to success in research; but granted an informed sympathy with the Africans, the American Negro should win his way where a white man cannot. Qualified men and women, after their research has been done in the field, ought to find teaching positions in American or African colleges.

' We hope that it may be possible to arrange for exchange of students between Fisk and 
African colleges. This would give admirable opportunities for the initiation of American students into African life.'

All these matters are keenly interesting to members of this Institute. We hope that Fisk will keep us informed about the progress of the scheme.

M. M. GREEN

\section{Australian Institute of Sociology}

THE Institute has received from the Australian Institute of Sociology an interesting publication called Social Horizons and dated July I943. It is a collection of articles on sociological subjects which will, if circumstances allow, be followed by further volumes. The articles are particularly concerned with the application of sociology to the present and future problems of Australia. There is also an obituary notice on Professor Malinowski paying tribute to his great gifts both as social anthropologist and as teacher.

\section{Primitive Art Exhibition, Melbourne, 1943}

THE exhibition of primitive art held at the National Gallery of Victoria includes works of plastic and graphic art from New Guinea, Melanesia, Polynesia, America, and Africa. The catalogue gives descriptions and reproductions of Bushman paintings, masks and statuettes, carved wood bowls, and other objects from the Belgian Congo, examples of Nupe brasswork and embroidery, brass statuettes from the Cameroons, and modern Bantu wood-carving from South Africa. In his introduction Mr. Leonhard Adam, Melbourne University Research Scholar in Anthropology, refers to the growing interest in primitive art, and its bearing on psychological and ethnological studies. 'The scientific study of primitive arts, art techniques and styles, the investigation of their historical developments and their religious and social functions is an important sub-division of ethnology.' Primitive art, though it has often evolved into more stylized or naturalistic forms, is distinguished by the qualities of spontaneity and sincerity. Mr. Adam refers to the effect on indigenous art of cultural influences from outside and of the introduction of European goods, particularly tools, which has been responsible for the deterioration, in technique and quality, of many primitive arts. With reference to African Negro sculpture, Mr. Adam thinks it unlikely that even the oldest Negro sculptures of wood, at present in European and American museums, can be older than a few centuries, but they were undoubtedly made with original African iron tools.

\section{Comments on F.M.O.'s article, 'Contribution to the Study of the Chronology of African Plastic Art.' Africa, vol. xiv, no. 4, October, x943.}

I Do not agree with the following statements in F.M.O.'s very interesting article. On p. 185 the author writes 'These data about Benin are of direct importance for the chronology of Central African art, for,' as he contends, 'the expansion of the art of Benin extended to the south-east, and very probably reached the Congo basin. Some even think that during one period of its history the political hegemony of Benin extended as far to the south as Angola.'

I do not know how this legend arose which made Benin into a huge empire, other authors even alleging that it reached as far north as the Gambia. Benin was always a small kingdom in size, and, for the greater part of its history, part of the Yoruba kingdom. The court historians at Benin still know in detail, from the twelfth century onwards, what countries or tribes were conquered by their kings, and these were only in the immediate neighbourhood of Benin; that is to say, at the height of its power the Benin kingdom only covered the southern part of what is now called Southern Nigeria. In addition, the Bini have never 